\title{
Luring back the exiles
}

\section{Budapest}

THE Hungarian research community is anxiously awaiting a decision later this month that could signal the beginning of a scientific renaissance. But its hopes are clouded by economic and other uncertainties.

At issue is a government proposal to double the Hungarian Research Fund (HRF) from 3,800 to 8,000 million forint ( $\$ 140$ million) over the next four years. If the proposal is approved, it will be a first step towards improving the country's economy through research, and, it is hoped, encouraging many of the large number of scientist emigrés to return to Hungary.

Like other new democracies in Eastern Europe, Hungary is entering a period of difficult choices, during which the inevitable economic and environmental crises will make it difficult to focus on improving the country's scientific base.

In some ways, Hungary is worse off than its neighbours. It is saddled with a foreign debt of $\$ 18,000$ million, more than any country in the region except Poland, while its 15-year start on a limited form of capitalism has exhausted many researchers, who have found it necessary hold second jobs.

But Hungary also has several advantages, including a long tradition of scientific excellence and a young population that is positively passionate about science. The past 15 years of relative openness have also brought rewards, such as better contacts for those who have stayed at home and a rich pool of successful Hungarians abroad.

The World Bank recognized this potential when it proposed a 'Human Resources Project', supported by a loan of at least $\$ 100$ million and likely to be approved in March 1991. Much of the money will be used to train young scientists, in contrast with projects in Poland and Romania which are focused on umemployment and health issues.

Within the government, there is strong political support for science. "The government understands that science and technology are the keys to a breakthrough for our economy", declares Ferenc Madl, minister without portfolio responsible for science. "We are committed to science and we have access to skilled people", he adds. "The basic problem is money."

Money is everyone's problem in Hungary. Uncertainty hangs over the research community, like society in general, because of inflation, which is officially acknowledged to be 30 per cent a year, but which some estimate to be 50 per cent. Economic difficulties have been further increased by a drop in exports and the loss of cheap oil from the Soviet Union. Support for October's blockade of all roads into and out of Hungary by taxi drivers protesting at higher petrol prices is seen as a signal that the government must aim at as smooth a transition as possible to a market economy.

In this light, the proposed doubling of the HRF seems remarkably generous, as long as the amounts are adjusted each year for inflation.

Madl has also persuaded the government to allow HRF funds to be drawn directly from the proceeds of a special 4.5 per cent tax on the profits of private businesses. Previously, the tax receipts of 8,000 million forint a year were used only for a fund for new technology. This change must also be approved by the parliament.

Unfortunately, the picture is not everywhere as rosy. The proposed salary increase for employees of the Academy of Sciences and universities is just 20 per cent and the budget for operating costs will rise only 10 per cent, far short of the "dream" figures of 30 and 50 per cent, respectively,

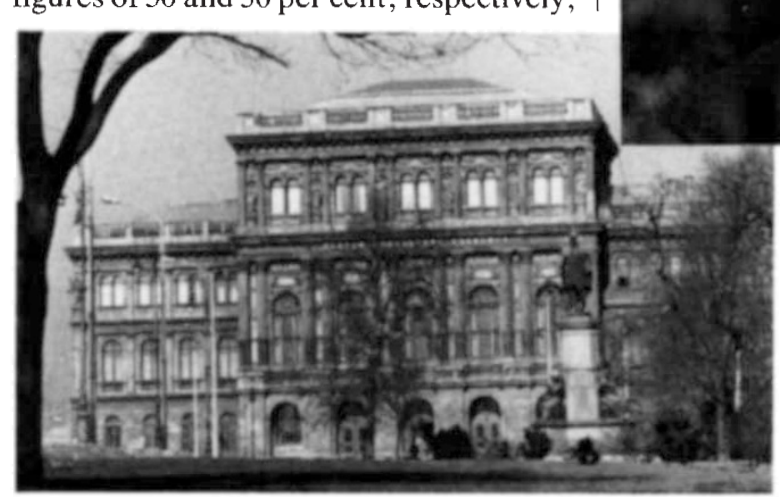

The Hungarian Academy of Sciences, Budapest, where "little castles" are in need of toppling, according to Ferenc Madl (right). proposed by Istvan Lang, secretarygeneral of the academy. At their current salaries, Lang explains, many researchers have to moonlight to make ends meet. "We will fight for more", he says.

Despite the promised increases, many researchers view the changes with suspicion. One young researcher, in his former institute on a brief visit from his current foreign post, summed up the general scepticism towards the promised increases: science, he says, "will be the first to be cut" if the budget shrinks.

And money is not the only problem. Researchers fear that the dominance of the academy over the universities will be reinforced if the government does not soon initiate a thorough reform. Madl agrees, saying he would like to "institutionalize" cooperation between the academy and the universities so that the former does more teaching and the universities gain freer access to research equipment.

Madl admits that many institute directors, especially in the academy, are jealously unwilling to "give up their little castles". But he forswears radical changes. The separation between the academy and the universities can be bridged only gradually, he says, on a caseby-case basis.

The academy answered some of these concerns at a meeting earlier this month, when it decided to select institute directors using more democratic processes, following up on efforts begun before the revolution.

Related to concerns about the power of the academy are suspicions that a group of insiders, not necessarily Communist Party members but rather an 'old-boy network', plays an inordinately large role in dividing up both domestic and foreign money.

For example, there are criticisms of the

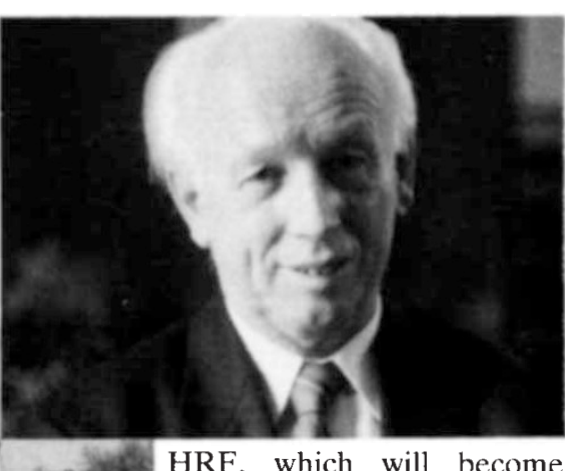
independent of the academy on 1 January, for allegedly unfair granting procedures that are said to favour politically powerful researchers at the expense of younger and potentially better-qualified people.

"Without an older sponsor", says one biologist, "it is impossible to receive money."

He says that some members of the grantmaking committees read only the names, not the proposals, in deciding who should be given money.

There is also confusion about a rumoured grant of 30 million ECU from the European Communities for materials research which, it is said, is being distributed by only five people without procedures for outside review

Madl says he "cannot imagine that this is true", but he accepts that the system might not yet be working perfectly. "Making peer review work properly is a problem even in the West", he says.

Nadl pleads for patience from the scientific refugees, acknowledging that only a prosperous economy will tempt them back. But time is running short. "A generation of our best students is now in graduate school abroad", says Alexander Szalay, an astrophysics professor at Eötvös University. "They will decide in three or four years if they want to return. If we lose them, it will take us 15 years to replace them." 